Check for updates

\title{
Blood Conservation Strategies in Total Hip and Knee Arthroplasty
}

\author{
David Liu, FRACS'; Michael Dan, MBBS ${ }^{2,3}$; Natalie Adivi, $B N^{1}$
}

\begin{abstract}
Peri-operative blood management is one of a number of components important for successful patient care in total joint arthroplasty and surgeons should be proactive in its application. The aims of blood conservation are to reduce the risks of blood transfusion whilst at the same time maximizing haemaglobin in the post-operative period, thereby leading to a positive effect on early and long term outcomes and costs. An individualized strategy based on patient specific risk factors, anticipated blood loss and co-morbidities is useful in achieving this aim. Multiple blood conservation strategies are available in the pre-operative, intra-operative and post-operative periods and can be utilised either individually or in combination. Recent literature has highlighted the importance of identifying and correcting pre-operative anaemia, salvaging peri-operative red cells and the use of tranexamic acid in reducing blood loss. Given total hip and knee arthroplasty is an elective procedure, a zero allogenic blood transfusion rate should be the aim and an achievable goal.
\end{abstract}

\section{Introduction}

One of a number of critical components for successful patient care in joint arthroplasty surgery is a blood management strategy. Hip and knee arthroplasty can result in substantial peri-operative blood loss, rendering the patients at increased risk of requiring a blood transfusion [1,2]. Total joint arthroplasty and fracture surgery is the number one reason for transfusion in patients undergoing surgery and accounts for $9.8 \%$ of all transfused red blood cell units [3]. Complications of allogenic blood transfusion include the risk of disease transmission, haemolytic reactions, fluid and haemodymanic overload, acute lung injury, coagulopathy, allergic reactions and febrile non-haemolytic reactions [4]. There is evidence that allogenic transfusions are associated with immunomodulation, and an increased incidence of infection [5]. Bierbaum reported transfusion rates of 57\% for total hip arthroplasty (THA) and 39\% for total knee arthroplasty (TKA), with an increased risk of fluid overload, infection rate and duration of hospitalization in the patients who received allogenic transfusion [6]. Several studies have highlighted the disadvantages of allogenic blood including a negative effect on postoperative complications, length of hospital stay, cost and mortality [7,8,9].

The fundamental aim of a blood management strategy is to eliminate the need for allogenic blood whilst at the same time preventing anaemia. Thereby the risks of transfusion are removed, haemaglobin $(\mathrm{Hb})$ status is maximized and this leads to a positive effect on the patient's recovery and early and long-term outcomes. Such a strategy should be individualized and based on patient specific

1 Gold Coast Centre for Bone and Joint Surgery, Suite 8A Fred McKay House, John Flynn Hospital, Inland Drive, Tugun, Queensland, Australia 4224

2 John Hunter Hospital, NSW, Australia.

3 Department of Medicine, Bond University, Gold Coast, Queensland Australia

(C) 2015 David Liu, Michael Dan, Natalie Adivi. All rights reserved DOI: 10.15438/rr.4.4.85 • ISSN 2331-2262 (print) • ISSN 2331-2270 (online)

For complete copyright and licensing information please refer to the end of this article. 
risk factors including pre-operative $\mathrm{Hb}$ level, anticipated difficulty of the procedure and blood loss, and associated medical co-morbidities. Haemaglobin loss in routine primary THA has been calculated to be $4.0 \mathrm{~g} / \mathrm{dL}$ and in TKA to be $3.8 \mathrm{~g} / \mathrm{dL}$ [10]. The ultimate transfusion trigger should also be individualized based on the risks and benefits for each patient. Multiple strategies, used either in isolation or combination, are available to reduce the need for allogeneic blood in joint arthroplasty patients. Available strategies can be broadly divided into 3 stages: pre-operative assessment and optimisation, intra-operative and post-operative protocols [11]. These are summarized in table 1.

Table 1. Summary of blood management interventions available to reduce allogenic transfusion rates in THA and TKA patients.

\begin{tabular}{|l|l|l|}
\hline Pre-operative & Intra-operative & Post-operative \\
\hline $\begin{array}{l}\text { Correcting anaemia } \\
\text { - Iron supplements } \\
\text { - Erythropoietin }\end{array}$ & $\begin{array}{l}\text { Acute normovolaemic } \\
\text { haemodilution }\end{array}$ & $\begin{array}{l}\text { Post-operative cell } \\
\text { salvage }\end{array}$ \\
\hline $\begin{array}{l}\text { Pre-operative } \\
\text { autologous blood } \\
\text { donation }\end{array}$ & $\begin{array}{l}\text { Intra-operative cell } \\
\text { salvage }\end{array}$ & $\begin{array}{l}\text { Re-infusion drain } \\
\text { No drain use }\end{array}$ \\
\hline $\begin{array}{l}\text { Ceasing antiplatelet } \\
\text { and anticoagulant } \\
\text { mediactions }\end{array}$ & $\begin{array}{l}\text { Tranexamic acid } \\
\text { - Intravenous }\end{array}$ & $\begin{array}{l}\text { Tranexamic acid } \\
\text { - Intravenous } \\
\text { - Topical }\end{array}$ \\
\hline
\end{tabular}

\section{Pre-operative Strategies}

Predicting the risk and need for transfusion pre-operatively has been shown to be an important element of an effective blood management program in joint arthroplasty surgery. Several studies have highlighted the significant influence of pre-operative $\mathrm{Hb}$ on the requirement for transfusion in total joint arthroplasty $[10,12]$. Salido et al demonstrated that very few patients with $\mathrm{Hb}$ greater than $150 \mathrm{~g} / \mathrm{L}$ pre-operatively required allogenic blood whilst patients with pre-operative $\mathrm{Hb}$ level less than $110 \mathrm{~g} / \mathrm{L}$ had a $100 \%$ transfusion rate [12]. Similarly, Pierson et al showed that an algorithmn based strategy aimed at improving pre-operative $\mathrm{Hb}$ level was the most effective in reducing transfusion rate [10]. Other risk factors associated with an increased need for transfusion include weight, age greater than 75 years, male gender, hypertension and body mass index less than 27 [13]. Whilst many of these factors are non-modifiable, Pola showed having more than one risk factor had a compounding effect on transfusion rate [14]. Therefore in patients with multiple risk factors, it is vitally important to correct anaemia and maximize pre-operative $\mathrm{Hb}$. Correcting anaemia not only reduces the risk of allogenic transfusion but also has a positive impact on the patient's rehabilitation and functional recovery. Patients with post-operative $\mathrm{Hb}$ of between 8 to $10 \mathrm{~g} / \mathrm{dl}$ may not be low enough to warrant transfusion but often feel lethargic, with a higher risk of syncopal episodes, impairing their ability to mobilize and undergo their rehabilitation.

In order to correct pre-operative anaemia, the cause needs to be fully investigated and corrected as necessary. A common reason, especially in the elderly arthroplasty patients, is iron deficiency due to a combination of poor dietary intake and peptic disease secondary to NSAID use. The typical pattern seen in these patients is low $\mathrm{Hb}$, with a low ferritin. In our centre, patients are screened 3 months prior to surgery with full blood count, proceeding to iron studies if the pre-operative $\mathrm{Hb}$ is less than $120 \mathrm{~g} / \mathrm{dL}$. The parameters measured to investigate pre-operative anaemia are listed in table 2 with the minimum cut-off values. Any patient who is identified as anaemic is referred to the haematology unit for further investigation and management.

Table 2. Pre-operative iron studies and critical values used at our institution for patients with pre-operative anaemia requiring correction prior to THA and TKA.

\begin{tabular}{|l|l|}
\hline Parameter & Critical Value \\
\hline Haemaglobin & $12 \mathrm{~g} / \mathrm{dL}$ \\
\hline Haematocrit & 0.38 \\
\hline Iron & $5 \mu \mathrm{mol} / \mathrm{L}$ \\
\hline Total Iron Binding Capacity & $45 \mu \mathrm{mol} / \mathrm{L}$ \\
\hline Transferrin Saturation & $20 \%$ \\
\hline Ferritin & $50 \mu \mathrm{g} / \mathrm{L}$ \\
\hline Vitamin B12 & $150 \mathrm{pmol} / \mathrm{L}$ \\
\hline RBC folate & $150 \mathrm{nmol} / \mathrm{L}$ \\
\hline
\end{tabular}

The options for maximizing $\mathrm{Hb}$ in preparation for surgery include iron supplements or erythropoietin. Iron supplements can either be given orally or intravenously. Both have been shown to be effective however oral iron may not be efficacious in patients with malabsorption such as coeliac disease. Another disadvantage of oral iron supplements is the slow effect and therefore it needs to be implemented well in advance of surgery. A cohort study of 156 patients treated with ferrous sulphate $256 \mathrm{mg}$ / day in with combination vitamin $C$ which enhances iron absorption, for 1 month preoperatively showed reduced a transfusion rate for non anemic patients [15]. For our patients with deficient iron stores, the haematologists administer 500-1000mg ferritin carboxymaltose as an intravenous infusion over 15 minutes. Dosage depends on the duration and severity of iron deficiency. The infusion needs to be given a minimum of 3 weeks pre-operatively to enable enough time for red blood cells to regenerate.

Erythropoeitin is a synthetic hormone, which stimulates progenitor cells in the bone marrow to differentiate into red blood cells and thereby stimulating haematopoi- 
esis. Erythropioetin is definitely a powerful agent in correcting anaemia and extremely effective in reducing allogenic blood requirement in joint replacement surgery. In a systematic review, Spahn [16] showed erythropoietin to be successful in improving mean preoperative $\mathrm{Hb}$ and post operative $\mathrm{Hb}$ with reduced transfusion rates when combined with iron therapy in patients undergoing orthopedic operations including hip fracture surgery, THA and TKA. Its main disadvantage remains cost and at this stage, its routine use in Australia is not approved in the joint replacement patients unless the patient suffers from anaemia secondary to chronic renal failure.

A large part of blood conservation in surgery is aimed at limiting blood loss. Patients undergoing THA and TKA frequently take antiplatelet and anticoagulant medications that affect the risk of bleeding. The decision and timing of cessation of antiplatelelet and anticoagulant therapy needs to take into consideration the risks of thrombosis versus the risk of bleeding. Platelet activation occurs with non-cardiac surgery, making myocardial infarction the most common major vascular complication after surgery. Under usual circumstances, warfarin should be discontinued 5 days prior to arthroplasty surgery [17] and recommenced postoperatively when the risks of acute bleeding are believed to be stable. Bridging anticoagulation therapy is commonly used in the interim period with agents such as low molecular heparin, which have a shorter half-life [18]. There are no clear guidelines or consensus on the optimal bridging therapy for patients on warfarin for conditions such as atrial fibrillation, previous embolic cerebrovascular events or mechanical valve replacement and further clinical trials are required to clarify the optimal regime.

With regards to aspirin and antiplatelet therapy, its cessation prior to surgery is believed to result in an increased risk of cardiovascular complications and major cardiac events $[19,20]$. However a recent large randomized controlled trial of 10010 patients of which 39\% underwent orthopaedic procedures, comparing aspirin versus placebo with 30 days follow up after surgery, found conflicting results [21]. There was no difference in the primary outcome of death or myocardial infarction between the 2 groups, regardless of whether the patient was taking aspirin prior to surgery or not. Aspirin increased the risk of major bleeding compared with placebo. The most common reported site of bleeding were the surgical site in $78.3 \%$ and gastrointestinal tract in $9.3 \%$. The authors concluded aspirin administration before surgery and throughout the early postsurgical period had no significant effect on the rate of a composite of death or nonfatal myocardial infarction but increased the risk of major bleeding. We now cease aspirin prior to THA and TKA.
Once popular in elective joint replacement surgery was pre-operative autologous donation. Autologous donation has been demonstrated to be effective in reducing allogenic blood requirements. Allogeneic transfusion rates were reduced from $40 \%, 52 \%$ and $91 \%$ in the non-preoperative autologous donation group to $3 \%, 18 \%$ and $9 \%$ respectively in the preoperative autologous donor group in three cohort studies $[22,23,24]$. However pre-operative autologous donation is associated with a high rate of wasted blood units and is no longer deemed to be cost effective. There remains the potential for the wrong blood being returned to the patient due to clerical errors $[25,26]$. The process itself necessitates the inconvenience of having to donate blood in advance of scheduled surgery. The Australian Blood Bank as a consequence currently imposes a cost to patients if they wish to utilize this service. The use of preoperative autologous blood donation has therefore fallen out of favour.

\section{Intra-operative Strategies}

A major element of intra-operative blood management is limiting the amount of blood loss. The risk of bleeding depends on the difficulty of the procedure and patient risk factors such as obesity, co-morbidities and bleeding disorders. Regardless of what additional strategies are incorporated, maintaining steady blood pressure and normothermia are both recommended in reducing blood loss. Crucial to blood loss management is meticulous efficient surgical technique with careful dissection, soft tissue handling and bleeding control.

The technique of acute normovolaemic haemodilution attempts to achieve a similar effect to pre-operative autologous blood donation but without the inconvenience of preoperative donation. Blood is collected from the patient in the immediate pre-operative period and volume is replaced with colloid or crystalloid fluid. The rationale behind the technique is surgical blood loss will have a lower haematocrit. The pre-operatively collected whole blood is transfused in the immediate post-operative period negating the downsides of blood storage. However the effectiveness of acute normovolaemic haemodilution in reducing transfusion need is debatable [16]. Its use may be appropriate in selected cases where cross matching of blood is difficult due to the presence of antibodies.

Peri- operative red cell salvage is another strategy available to minimize the effects of blood loss following total hip and knee arthroplasty. Blood lost during the operative procedure and immediate post-operative period can be salvaged and returned to the patient. This technique has sev- 
eral advantages over the previously described methods of pre-operative autologous donation and acute normovolaemic haemodilution. Peri-operative red cell salvage re-infuses fresh blood and avoids the problems with storage of red blood cells seen with autologous pre-donation and allogeneic red blood cells. This translates to more efficacious oxygen carrying red blood cells with a higher mean erythrocyte viability [27] and increased preservation of 2-3 diphosphoglycerate [28]. The technique also incorporates washing the blood loss volume. Washing the blood removes biochemical, cellular and non-cellular debris [29]. Unwashed cell salvage has been associated with adverse post-operative effects due to the presence of cytokines including hypotension, hyperthermia, increased postoperative bleeding and non-cardiogenic pulmonary edema. [30, 31] We have been using intra-operative red cell salvage in our unit for the past 4 years for primary and revision hip and knee replacement. An audit of our transfusion rates in comparison to other studies in the literature is listed in table 3 for THA $[32,33,34]$ and table 4 for TKA. [35,36,37] Peri-operative red cell salvage definitely reduces but does not eliminate the need for allogenic blood, especially in patients who have a low baseline haemaglobin pre-operatively.

Table 3. Effects on Allogenic Transfusion Rates of autologous retransfusion of salvaged blood cells in randomized controlled trials and cohort studies for THA compared to historical rate reported by Bierbaum without intervention.

\begin{tabular}{|l|l|l|l|l|l|}
\hline Study & $\begin{array}{l}\text { Bierbaum } \\
{[\mathbf{6}]}\end{array}$ & $\begin{array}{l}\text { del Trujilo } \\
{[\mathbf{3 2}]}\end{array}$ & $\begin{array}{l}\text { Smith } \\
{[\mathbf{3 3}]}\end{array}$ & Moonen [34] & Our Data \\
\hline $\begin{array}{l}\text { Allogenic } \\
\text { Transfusion } \\
\text { Rate }\end{array}$ & $57 \%$ & $15 \%$ & $8 \%$ & $6 \%$ & $23.7 \%$ \\
\hline
\end{tabular}

Table 4. Effects on Allogenic Transfusion Rates of autologous retransfusion of salvaged blood cells in randomized controlled trials and cohort studies for TKA compared to historical rate reported by Bierbaum without intervention.

\begin{tabular}{|l|l|l|l|l|l|}
\hline Study & $\begin{array}{l}\text { Bierbaum } \\
{[\mathbf{6}]}\end{array}$ & $\begin{array}{l}\text { Shenolikar } \\
{[\mathbf{3 5}]}\end{array}$ & $\begin{array}{l}\text { Thomas } \\
{[\mathbf{3 6}]}\end{array}$ & $\begin{array}{l}\text { Munoz } \\
{[\mathbf{3 7}]}\end{array}$ & Our Data \\
\hline $\begin{array}{l}\text { Allogenic } \\
\text { Transfusion } \\
\text { Rate }\end{array}$ & $39 \%$ & $16 \%$ & $7 \%$ & $11 \%$ & $11.9 \%$ \\
\hline
\end{tabular}

\section{Post-operative Strategies}

The routine use of intra-articular wound drainage in THA and TKA has been shown to increase blood transfusion requirement [38]. This needs to be balanced with the reported increased risk of persistent ooze, bruising and haematoma formation [39]. The evidence for use of an intra-articular drain therefore remains inconclusive and very much an individual decision based on surgeon preference.

Post-operative reinfusion drains are also commonly employed in orthopaedic practice and reported results suggest it does reduce allogeneic transfusion rates. A metaanalysis by Huet et al [30] showed a relative risk reduction of 0.35 for the need for allogeneic transfusion with re-infusion drains. Zacharopoulos performed a prospective randomized controlled trial with reinfusion drains, leading to a decrease in allogenic blood transfusion [40]. In contrast, Hazarika showed reinfusion drains had no significant benefit with the downside of additional costs [41]. Reinfusion drains carry the potential for transfusion reactions as the unwashed blood contains fibrin degradation products and other potential contaminants $[42,43]$. The drained blood needs to be reinfused with 6 hours of commencement to avoid the potential for haemolysis.

A logical strategy in blood conservation is to enhance haemostasis during the peri-operative period. Recently a multitude of publications have highlighted the use and benefits of antifibrinolytic agents. Tranexamic acid (TXA) is one such agent being a synthetic plasminogen-activator inhibitor, showing both clinical efficacy and an acceptable safety profile. TXA inhibits the activation of plasminogen to plasmin by blocking the lysine binding sites of plasminogen to fibrin. This results in a decrease in proteolytic action on fibrin monomers and fibrinogen, leading to clot stabilization [44]. The use of TXA in primary THA and TKA patients has been associated with reduced transfusion rates, increase discharge rate to home, and reduced costs [45].

Tranexamic acid has the desirable features of ease of administration, minimal effect on operative procedure flow, and extremely low cost as a generic medicine. Intravenous TXA has been demonstrated to significantly reduce the amount of blood loss and blood transfusion requirements without an increase in venous thromboembolic risk in multiple studies for both THA and TKA $[46,47,48]$. Oral TXA has also shown similar effectiveness in orthopadic surgery [49]. Several contra-indications preclude the use of intravenous TXA at the time of surgery, including renal insufficiency, history of previous deep venous thrombosis, cerebrovascular and cardiac disease. One study reported $28 \%$ of patients were contraindicated to intravenous TXA [50] and in these patients topical administration nay be more appropriate due to the delay in systemic absorption after application into a joint. Intra-articular application limits systemic exposure and maximizes drug concentration and activity directly at the site of bleeding. Wong et al proved the efficacy of intra-articular TXA in a double-blind, placebo-controlled randomized trial in TKA [51]. The authors demonstrated a significant difference in $\mathrm{Hb}$ reduction and blood loss using $3.0 \mathrm{~g}$ of TXA in $100 \mathrm{mls}$ of normal saline compared to placebo, with no difference in thrombo-embolic complications. Plasma levels of TXA 
following topical administration were $70 \%$ less than an equivalent dose of intravenous injection. More recently, a retrospective study found intra-articular and pericapsular injection of TXA after capsular closure resulted in a transfusion rate reduction from $17.5 \%$ to $5.5 \%$ as well as a significantly higher post-operative $\mathrm{Hb}$ in the TXA group [45]. Alshryda et al performed a systematic review and metaanalysis showing topical TXA to significantly reduce the rate of blood transfusion in both THA and TKA and was safe [52]. Indirect comparison of placebo-controlled trials indicated topical administration to be superior to the intravenous route.

There is however no clear consensus on ideal dosage, timing, frequency and routes for administration of TXA in joint arthroplasty surgery. Additionally there may be differences in the efficacy and response of different regimes between THA and TKA. A number of studies have now compared intravenous TXA with topical TXA demonstrating the efficacy and safety of topical administration in TKA [53,54,55]. Both Patel at al [50], using a single intravenous dose and Soni et al [56], using a 3 dose intravenous regimen concluded topical TXA had similar efficacy to intravenous TXA in terms of perioperative change in haemaglobin, lowest postoperative haemoglobin, total drain output and transfusion rate, together with no increase in complications in randomized prospective studies. In a study comparing 3 methods of administration in TKA, single dose intravenous TXA was more effective than topical and intra-articular TXA injected via the drain in reducing $\mathrm{Hb}$ drop [57]. Local administration through the drain yielded least blood drainage post-operatively compared to intravenous and topical application, with $80 \%$ reduction drainage volume compared to $45 \%$ and $18 \%$ respectively. In contrast, Maniar et al found single intravenous dose did not give effective results [58]. A 3-dose regimen of pre, intra and post-op doses of $10 \mathrm{mg} / \mathrm{kg}$ produced maximum effective reduction of drain loss and total blood loss in TKA. The authors concluded a pre-operative dose prior to tourniquet inflation was important to inhibit the activation of the fibrinolysis cascade.

There are fewer studies examining the utility of topical TXA in THA. Wind et al showed a significant reduction in transfusion rate with intravenous TXA in THA but not with topical TXA [59]. Alshryda et al in contrast published a significant reduction in rate of transfusion with topical TXA in THA, comparable to that achieved with TKA [60]. Studies from Konig et al and Tuttle et al both revealed topical TXA to be efficacious in THA as well $[45,61]$.

Another form of pharmacotherapy used to reduce blood loss is topical fibrin sealant. These agents are composed of fibrinogen and thrombin, which when mixed together dur- ing the application process, mimic the final step of the coagulation cascade. Randelli performed a randomized trial of topical fibrin versus a control group but found no difference in $\mathrm{Hb}$ levels, postoperative decrease in $\mathrm{Hb}$, drainage or mean total blood loss [62]. In particular, the transfusion rate was $32.3 \%$ in the control group compared with $25.8 \%$ in the fibrin group and this was not significantly different. The authors concluded the topical application of fibrin sealant was not effective in reducing peri-operative blood loss in total knee arthroplasty. Another randomized study comparing topical fibrin spray to intravenous TXA demonstrated comparable reduction in blood loss but the cost of the fibrin spray was significantly greater [63].

\section{Conclusions}

A blood management strategy in total joint arthroplasty aims to reduce the need for allogenic blood and avoid the risks of transfusion, whilst at the same time maximizing haemaglobin level and preventing anaemia in the acute post-operative period. Effective blood conservation encompasses pre-operative identification of patients at high risk for transfusion, correcting pre-operative anaemia with haemopoietic agents, salvaging blood lost during the perioperative period, limiting post-operative blood loss with haemostatic measures and individualizing the transfusion trigger according to the patient's symptoms and medical co-morbidities. The algorithm used in our unit is shown in figure 1. A proactive approach to blood management will lead to a positive effect on early and long-term outcomes and greater success in care of the joint arthroplasty patient.

\section{References}

1. Eubanks JD. Antifibrinolytics in major orthopaedic surgery. J Am Acad Orthop Surg 2010; 18: 132-8

2. Noticewala MS, Nyce JD, Wang W, et al. Predicting need for allogenic transfusion after total knee arthroplasty. J Arthroplasty 2012; 27(6): 961

3. Shortt J, Polizzotto MN, Waters N, et al. Assessment of the urgency and deferability of transfusion to inform emergency blood planning and triage: the Bloodhound prospective audit of red blood cell use. Transfusion 2009; 49 (11): 2296-2303

4. Goodnough LT, Shuck JM. Risks, options, and informed consent for blood transfusion in elective surgery. Am J Surg 1990; 159(6): 602

5. Keating EM, Meding JB. Perioperative blood management practices in elective orthopaedic surgery. J Am Acad Orthop Surg 2002; 10:393-400

6. Bierbaum BE, Hill C, Callaghan JJ, et al. An analysis of blood management in patients having a total hip or knee arthroplasty. J Bone Joint Surg Am1999; 81(1): 2-10

7. Hébert PC, Wells G, Tweedale M, et al. Does transfusion practice affect mortality in critically ill patients? Transfusion Requirements in Critical Care (TRICC) Investigators and the Canadian Critical Care Trials Group. Am J Respir Crit Care Med 1997; 155(5): 1618-23

8. Bernard AC, Davenport DL, Chang PK, et al. Intraoperative transfusion of $1 \mathrm{U}$ to $2 \mathrm{U}$ packed red blood cells is associated with increased 30-day mortality, surgicalsite infection, pneumonia, and sepsis in general surgery patients. J Am Coll Surg 2009, 208(5): 931-7

9. Bower WF, Jin L, Underwood MJ, et al. Peri-operative blood transfusion increases length of hospital stay and number of post-operative complications in non-cardiac surgical patients. Hong Kong Med J 2010; 16 (2): 116 


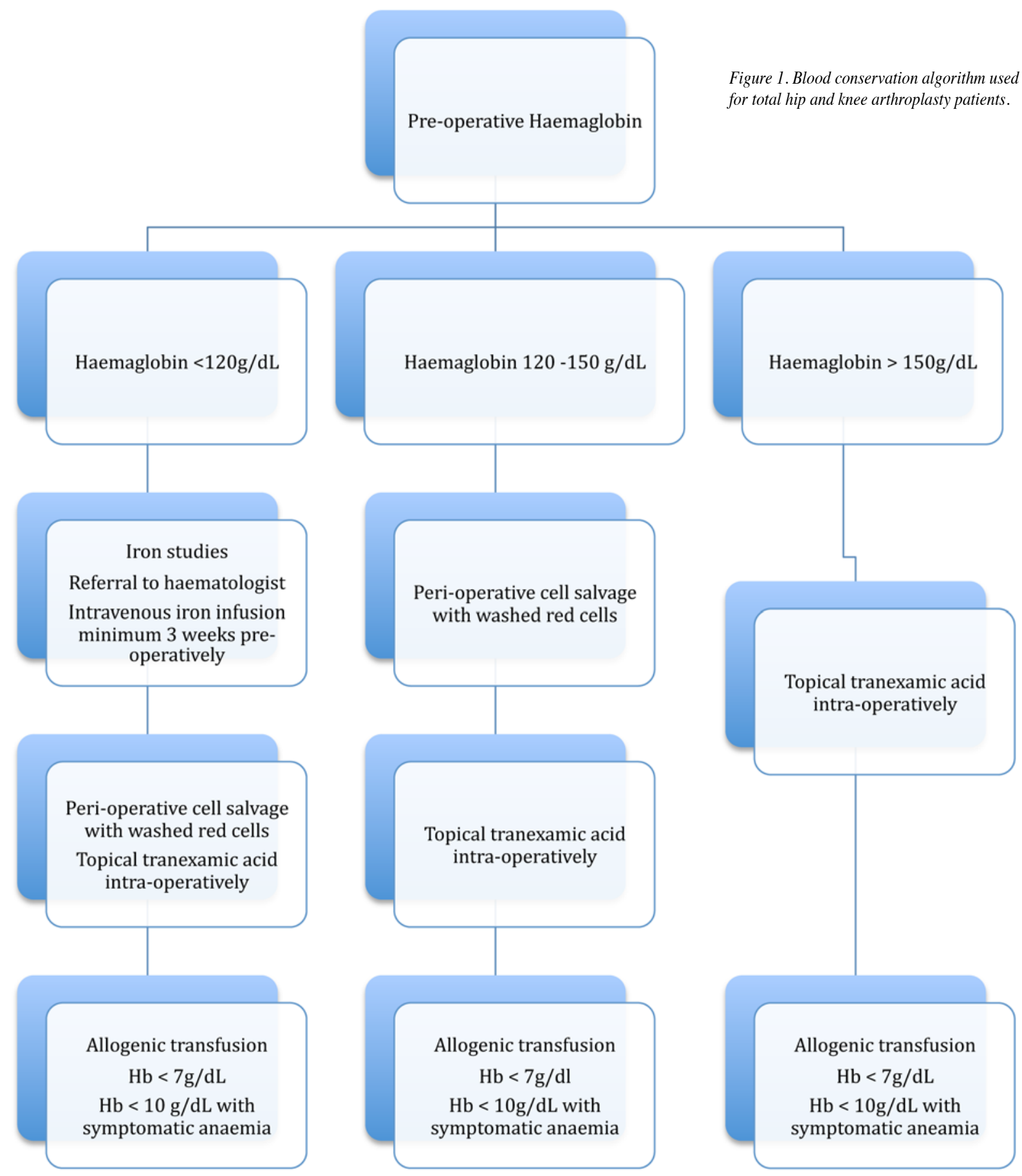

10. Pierson JL, Hannon TJ, Earles DR. A blood-conservation algorithm to reduce blood transfusions after total hip and knee arthroplasty. J Bone Joint Surg Am 2004; 86(7): 1512-1518

11. Krebs V, Hozack WJ, Callaghan JJ, et al. Eliminating transfusion in primary joint arthroplasty- an achievable goal. J Arthroplasty 2014; 29(8): 1511

12. Salido JA, Martin LA, Gomez LA, et al. Pre-operative hemoglobin levels and the need for transfusion after prosthetic hip and knee surgery: analysis of predictive factors. J Bone Joint Surg Am 2002; 84(2): 216

13. Bong MR, Patel V, Chang E, et al. Risks associated with blood transfusion after total knee arthroplasty. J Arthroplasty 2004; 19(3): 281

14. Pola E, Papaleo P, Santoliquido A, et al. Clinical factors associated with an increased risk of perioperative blood transfusion in nonanemic patients undergoing total hip arthroplasty. J Bone Joint Surg Am 2004; 86(1): 57-61

15. Cuenca JI, Garcia-Erce JA, Martinez F et al. Pre-operative haematinics and transfusion protocol reduce the need for transfusion after total knee replacement. Int J Surg 2007; 5 (2): 89-94
16. Spahn D. Anaemia and patient blood management in hip and knee surgery. Anaesthesiology 2010; 113 (2): 482-95

17. Arthroplasty Society of Australia. Guidelines for venous thrombotic episode prophylaxis for hip and knee arthroplasty. Australian Orthopaedic Association 2010.

18. Bruce W, Campbell D, Daly D, et al. Practical recommendations for patient blood management and the reduction of perioperative transfusion in joint replacement. ANZ J Surg.; 83 (4): 222-229

19. Burger W, Chemnitius JM, Kneissl GD, et al. Low-dose aspirin for secondary cardiovascular prevention- cardiovascular risks after its peri-operative withdrawl versus bleeding risks with its continuation- review and meta-analysis. J. Intern. Med. 2005; 257:399-414

20. Oscarsson A, Gupta A, Fredrikson M et al. To continue or discontinue aspirin in the perioperative period: a randomized, controlled clinical trial. Br. J. Anaesth. 2010; 104: 305-12

21. Devereaux PJ, Mrkobrada M, Sessler DI et al. Aspirin in patients undergoing noncardiac surgery. N Engl J Med 2014; 370(16): 1494-503 
22. Cushner FD, Scott WN, Scuderi G, et al. Blood loss and transfusion rates in bilateral total knee arthroplasty. J Knee Surg 2005; 18: 102-7

23. Biesma DH, Marx JJ, Kraaijenhagen RJ, et al. Lower homologous blood requirement in autologous blood donors after treatment with recombinant human erythropoietin. Lancet 1994; 344: 367-70

24. Sharland MG, Holman PR: Autologous blood donation in total hip replacement. ANZ J Surg 1995; 65(1): 17-9

25. Cohen JA, Brecher ME. Preoperative autologous blood donation: benefit or detriment? A mathematical analysis. Transfusion 1995; 35(8): 640-4

26. Birkmeyer JD, Goodnough LT, AuBuchon JP, et al.The cost-effectiveness of preoperative autologous blood donation for total hip and knee replacement. Transfusion 1993, 33: 544-551

27. Krajewski K, Ashley RK, Pung N, et al. Successful blood conservation during craniosynostotic correction with dual therapy using Procrit and cell saver. J Caraniofac Surg 2008; 19: 101-5.

28. Munoz Gomez M, Sanchez Arrieta Y, Garcia Vallejo JJ, et al. Pre and post-operative autotransfusion. A comparative study of hematology, biochemistry and red cell metabolism in pre-donated blood and blood from post-operative surgical drainage. Sangre (Barc) 1999; 44(6): 443-50

29. Noon GP. Intraoperative autotransfusion. Surgery 1978; 84: 719-721

30. Huet C, Salmi R, Fergusson D, et al. A meta-analysis of the effectiveness of cell salvage to minimize perioperative allogeneic blood transfusion in cardiac and orthopedic surgery. Anesth Analg 1999; 89(4): 861-869.

31. Faught, C, Wells P, Fergusson D, et al. Adverse effects of methods for minimizing perioperative allogeneic transfusion: a critical review of the literature. Transfus Med Rev 1998; 12(3): 206-225

32. del Trujillo MM, Carrero A, Munoz M. The utility of the perioperative autologous transfusion system OrthoPAT in total hip replacement surgery: A prospective study. Arch Orthop Trauma Surg 2008; 128: 1031-8

33. Smith LK, Williams DH, Langkamer VG. Post-operative blood salvage with autologous retransfusion in primary total hip replacement. J Bone Joint Surg Br 2007; 89: 1092-7

34. Moonen AF, Knoors NT, van Os JJ, et al. Retransfusion of filtered shed blood in primary total hip and knee arthroplasty: A prospective randomized clinical trial. Transfusion 2007; 47: 379-84

35. Shenolikar A, Wareham K, Newington D, et al. Cell salvage auto transfusion in total knee replacement surgery. Transfus Med 1997; 7: 277-80

36. Thomas D, Wareham K, Cohen D, et al. Autologous blood transfusion in total knee replacement surgery. Br J Anaesth 2001; 86: 669-73

37. Munoz M, Ariza D, Garceran MJ, et al. Benefits of postoperative shed blood reinfusion in patients undergoing unilateral total knee replacement. Arch Orthop Trauma Surg 2005; 125: 385-9

38. Parker MJ, Livingstone V, Clifton R, McKee A. Closed suction surgical wound drainage after orthopaedic surgery. Cochrane Database Syst. Rev 2007; 18(3): CD001825

39. Kumar S, Penematsa S, Parekh S. Are drains required following routine primary total joint arthroplasty? Int. Orthop. 2007; 31: 593-6

40. Zacharopoulos A, Apostolopoulos A, Kyriakidis A. The effectiveness of reinfusion after total knee replacement. A prospective randomized controlled study. Int. Orthop. 2007; 31: 303-8

41. Hazarika S, Bhattacharya R, Bhavikatti M, et al. A comparison of post-op haemaglobin levels and allogenic blood transfusion rates following total knee arthroplasty without drainage or with reinfusion drains. Acta Orthop. Belg. 2010; 76: 74-8

42. Dalen T, Bengtsson A, Brorsson B, et al. Inflammatory mediators in autotransfusion drain blood after knee arthroplasty, with and without leucocyte reduction. Vox Sang 2003; 85(1): 31-9

43. Hansen E, Hansen MP. Reason against the retransfusion of unwashed wound blood. Transfusion 2004; 44 (12 Suppl): 45S-53S

44. Dunn CJ, Goa KL. Tranexamic acid: a review of its use in surgery and other indications. Drugs 1999; 57(6): 1005

45. Tuttle JR, Ritterman SA, Cassidy DB, et al. Cost benefit analysis of topical tranexamic acid in primary total hip and knee arthroplasty. J Arthroplasty 2014; 29(8): 1512

46. Yang ZG, Chen WP, Wu LD. Effectiveness and safety of tranexamic acid in reducing blood loss in total knee arthroplasty: a meta-analysis. J Bone Joint Surg Am 2012; 94(13): 1153-1159

47. Alshryda S, Sarda P, Sukeik M et al. Tranexamic acid in total knee replacement: a systematic review and meta-analysis. J Bone Joint Surg Br 2011; 93(12): 1577 1585

48. Sukeik M, Alshryda S, Haddad FS, et al. Systematic review and meta-analysis of the use of tranexamic acid in total hip replacement. J Bone Joint Surg Br 2011; 93(1): $39-46$
49. Kagoma YK, Crowther MA, Douketis J, el al. Use of antifibrinolytic therapy to reduce transfusion in patients undergoing orthopedic surgery: a systematic review of randomized trials. Thromb Res 2009; 123: 687

50. Patel JN, Spanyer JM, Smith LS, et al. Comparison of intravenous versus topical tranexamic acid in total knee arthroplasty: a prospective randomized study. J Arthroplasty 2014; 29(8): 1528

51. Wong J, Abrishami A, El Beheiry H, et al. Topical application of tranexamic acid reduces postoperative blood loss in total knee arthroplasty: a randomized, controlled trial. J Bone Joint Surg Am 2010; 92(15): 2503-2513

52. Alshryda S, Sukeik M, Sarda P, et al. A systematic review and meta-analysis of the topical administration of tranexamic acid in total hip and knee replacement. Bone Joint J 2014; 96(8): 1005

53. Seo JG, Moon YW, Park SH, et al. The comparative efficacies of intra-articular and IV tranexamic acid for reducing blood loss during total knee arthroplasty. Knee Surg Sports Traumatol Arthrosc 2013; 21(8): 1869

54. Wind TC, Barfield WR, Moskal JT. The effect of tranexamic acid on blood loss and transfusion rate in primary total knee arthroplasty. J Arthroplasty 2013; 28(7): 1080

55. Ishida $\mathrm{K}$, Tsumura $\mathrm{N}$, Kitagawa $\mathrm{A}$, et al. Intra-articular injection of tranexamic acid reduces not only blood loss but also knee joint swelling after total knee arthroplasty. Int Orthop 2011; 35(11): 1639

56. Soni A, Saini R, Gulti A, et al. Comparison between intravenous and intra-articular regimens of tranexamic acid in reducing blood loss during total knee arthroplasty. J Arthroplasty 2014; 29 (8): 1525

57. Sarzaeem MM, Razi M, Kazemian G, et al. Comparing efficacy of three methods of tranexamic acid administration in reducing haemaglobin drop following total knee arthroplasty. J Arthroplasty 2014; 29(8): 1521

58. Maniar RN, Kumar G, Singhi T, et al. Most effective regimen of tranexamic acid in knee arthroplasty. A prospective randomized controlled study in 240 patients. Clin Orthop Relat Res 2012; 470(9): 2605

59. Wind TC, Barfield WR, Moskal JT. The effect of tranexamic acid on transfusion rate in primary total hip arthroplasty. J Arthroplasty 2014; 29(2): 387-9

60. Alshryda S, Mason J, Sarda P, et al. Topical (intra-articular) tranexamic acid reduces blood loss and transfusion rates following total hip replacement: a randomized controlled trial (TRANX_H). J Bone Joint Surg Am 2013; 95(21): 1969-1974

61. Konig G, Hamlin BR, Waters JH. Topical tranexamic acid reduces blood loss and transfusion rates in total hip and knee arthroplasty. J Arthroplasty 2013; 28(9): 1473

62. Randelli F, D'Anchise R, Ragone V, et al. Is the newest fibrin sealant an effective strategy to reduce blood loss after total knee arthroplasty? A randomized controlled study. J Arthroplasty 2014; 29(8): 1516-1520

63. Molloy DO, Archbold HA, Ogonda L, et al. Comparison of topical fibrin spray and tranexamic acid on blood loss after total knee replacement: a prospective, randomized controlled trial. J Bone Joint Surg Br 2007; 89(3): 306

\section{Copyright \& Licensing}

Authors retain copyright and grant the journal right of first publication with the work. Reconstructive Review follows the Creative Commons Attribution-NonCommercial CC BY-NC. This license allows anyone to download works, build upon the material, and share them with others for non-commercial purposes as long as they credit the senior author, Reconstructive Review, and the Joint Implant Surgery \& Research Foundation (JISRF). An example credit would be: "Courtesy of (senior author's name), Reconstructive Review, JISRF, Chagrin Falls, Ohio". 